\title{
COVID-19 Lessons to learn
}

\author{
Yong Yau Ong* \\ Department of Internal Medicine, Singapore General Hospital, Singapore
}

\section{Short communication}

COVID-19 is now a household word that the world had not heard before December 2019. A pandemic with both a fast spreading public health and economic crises. This paper is written by a clinician and not an epidemiologist and by one who has lived through SARS and now experiencing the COVID-19 epidemic like everyone.

The WHO Director-General Dr Tedros Adhanon Ghebreyesus is right when he said,

“...to save lives we must reduce transmission that means finding and isolating as many cases as possible and quarantining their closest contacts..." [1].

Those who have experienced Severe Acute Respiratory Syndrome (SARS) will tell you that these viruses are no respector of persons. To treat them lightly would be a grave mistake as it would result in an exacting toll. There is already a plethora of papers on the subject hence this is being written with a sense of reluctance but a hope that it will help those facing this kind of crisis for the first time.

By now the world has come to know about its transmissibility. I wish to look at some examples from the Singapore experience.

The first cluster was when a group of 20 tourists ( 2 members known to have coronavirus) from Southern China visited a Chinese Health products shop on January 22 2020. Two women employees of the shop contracted the virus. One employee subsequently went on to infect her husband, their domestic maid helper and their 6-month old son. The tour guide for the group was also infected. Apart from visiting 6 other places, they travelled to Malaysia too [2].

The second cluster came about as a result of an international business meeting at a well-known local hotel. Of the multi-national composition of the 109 attendees one was a Chinese delegate from Wuhan, the epicenter of the coronavirus outbreak. This cluster attracted international attention as the meeting is linked to cases in 3 other countries - Two South Koreans, one Malaysian, three Singaporeans and one national from the United Kingdom [3]. The Malaysian subsequently infected his sister and mother in-law. While the returning UK citizen infected some 7 of his fellow countrymen, some while at a ski resort in France [4].

The third illustration is of a religious organization involving two different churches. The first church involved two Chinese nationals from Wuhan who attended the first Church and infected 6 individuals. A couple from the same Church subsequently was found to have contracted the infection from the Wuhan nationals. The infected couple attended a Chinese New Year gathering in which a Church administrative worker from another Church also attended. He was infected and brought the infection back to his own Church [5]. The spread occurred through devotion and prayer meetings. Both churches accounted for a cluster of 32 infected individuals.
Associate Professor Hsu Li Yang of the National University of Singapore's Saw Swee Hock School of Public Health said "This is not limited to churches or other house of worship but anytime there is a large crowd in very close proximity for a considerable period of time, the potential for transmission of one or a few members who are infected will be high, particularly if the location is air-conditioned or has poor ventilation" [6].

The last illustration is of a dinner event attended by 200 people. The venue also hosted another event with 400 guests. Much social interaction occurred including song and dance performances and people were in close proximity with one another [7]. One of the local attendees had gone to the dinner despite feeling unwell. The person subsequently tested positive for COVID-19. This cluster resulted in 36 infected individuals. Even though they had respiratory symptoms some of the infected people still continued with normal activities, socializing and going to work [8].

If we look at the above clusters it shows how transmission took place through daily activities. Like attending a convention, tourists shopping, religious activities and social functions. If the experiences we have had can be multiplied by many times in a larger city or country it could account for the scenario we are seeing world-wide. The infected affecting others and spreading beyond a country's borders. It also explains the exponential rise in infected cases we are currently seeing. The sheer speed, scale and scope is different from anything we have had before.

Quo Vadis. The countries that will come out with flying colors are those with strong leadership from government and the professional healthcare specialists. They should not be afraid to make informed measured decisions and also be prepared to take the flak at this crucial time. Public interest and safety should be paramount and societal behavioural norms and values need to change. Stringent hygiene practices such as hand washing, cough etiquette, safe distancing need to be enforced and honored. Personal protection equipment like masks, gloves, goggles, and isolation gowns are important and guidelines for their proper use must be followed to the very letter. Travel restriction and stay home advisories are already present in many countries to restrict people movement. A small group in many societies continue to flout these measures and need to be reminded constantly through communications and the media not to put others at risk. People who are ill should not go out to work but see a doctor.

To stop the virus from spreading requires strict isolation and quarantine. In Singapore anyone who tests positive is kept in hospitals.

${ }^{*}$ Correspondence to: Yong Yau Ong, Emeritus Consultant, Department of Internal Medicine, Singhealth, Singapore, E-mail: ong.yong.yau@singhealth.com.sg

Received: April 21, 2020; Accepted: May 04, 2020; Published: May 07, 2020 
People who have had contact but who have no symptoms are kept in strict home quarantine. Hiving off people and taking care of them till the virus clears works said Prof Dale Fisher, Chair WHO Global Outbreak Alert \& Response Network [9].

Isolation beds were in short supply during SARS and we converted containers into isolation facilities. We used modified industrial fans and plywood boards to create negative pressure rooms and segregate and lockdown wards. It is important to triage patients with fever from the general patients at the Emergency room. Also the importance of limitation and registration of hospital visitors, similar to the current practice [10]. And as far as possible those with respiratory symptoms are segregated from the usual cases in the wards. Just like SARS, COVID-19 virus can contaminate environmental surfaces in the hospitals, equipment and machines used by patients and precautions are necessary to reduce respiratory or faecal contamination.

The Ministry of Health has teams checking on close contacts of coronavirus patients to see if they are well or have symptoms and be treated as a suspect case and hospitalized. Their job of contact tracing is a critical part of ring-fencing the virus by rounding up people who may have been infected [11]. It involves players like hospitals, the police with professional investigators, statutory boards, security officers, paramedic and the Government Technology Agency [12].

We have done more coronavirus swab testing than many other countries being early with this diagnostic tool. It can reveal the extent of the outbreak and give a clear handle on how many are infected.

Here in Singapore we have come a long way since SARS and the painful lessons. There are more trained infectious diseases specialists, epidemiologist and public health specialists than in 2003. Many countries need to be equipped and ready for new emerging infections. Since SARS we have built more general hospitals and we have the new National Centre for Infectious Diseases (NCID).

It is not "business as usual" said Minister Lawrence Wong (Cochair, Multi-ministry task force to fight the coronavirus). Indeed even leisure activities are affected. The infamous cruise liner the Diamond Princess with many infected passengers and crew had inadequate infection and hygienic measures on board [13].

On the other hand the cruise liner Costa Fortuna left Singapore with a passenger load of 1,631 some from Europe. They left and returned to port after 6 days at sea having been turned away by other destinations. However, to date they embarked and returned well. All passengers were thoroughly screened before and after disembarkation [14].

As I conclude this paper the number of coronavirus in the community has moderated. As on 13 April 2020 there were 141 migrant work permit holders who became infected; residing in dormitories, work sites and other living quarters [15]. Clusters at foreign worker dormitories continue to grow rapidly. Some are factory-converted dormitories. Making up to $60 \%$ of Singapore cases [16]. Many of the foreign workers are of Indian or Bangladesh nationals in the construction industry. They are being isolated, tested and rehoused to prevent clusters from forming. They pose another lesson to learn from this epidemic.

In the words of our Minister for Health, Mr. Gan Kim Yong to Parliament and I quote "The months ahead will be challenging. We need to be prepared for disruption to our daily lives and changes to how we do things. But I am confident that if we stay united, with a whole-of-society effort we can get through this together."

\section{Acknowledgements}

The author thanks Ms Tan Geok Eng for helping in the preparation and submission of the manuscript.

\section{Declaration of conflicting interests}

The author reports no conflicts of interest. The author alone is responsible for the content and writing of this article.

\section{Funding}

This paper received no specific grant from any funding agency in the public, commercial, or not-for-profit sectors.

\section{References}

1. World Health Organization (2020) WHO Director-General's opening remarks at the Mission briefing on COVID-19- 12 March 2020, https://www.who.int/dg/speeches/ detail/who-director-general-s-opening-remarks-at-the-mission-briefing-on-covid-19--12-march-2020

2. Tee Z (2020) All 7 locally transmitted cases linked to tour group from China. The Straits Times, 6 February 2020, https://www.straitstimes.com/singapore/all-7-locallytransmitted-cases-linked-to-tour-group-from-china?

3. More than 100 people attended meeting at Grand Hyatt Singapore linked to Malaysia South Korea coronavirus cases. Channel NewsAsia, 6 February 2020, https://www. channelnewsasia.com/news/singapore/wuhan-coronavirus-grand-hyatt-meetingmalaysia-korea-12398310

4. Five Britons in French ski resort catch coronavirus after contact with man who had been in Singapore. Channel NewsAsia, 9 February 2020, https://www.channelnewsasia. $\mathrm{com} /$ news/world/wuhan-virus-five-britons-french-ski-resort-coronavirussingapore-12411224

5. Ministry of Health, Singapore. Links established between church clusters and wuhan travellers report. Ministry of Health, Singapore, 25 February 2020, https://www.moh. gov.sg/news-highlights/details/links-established-between-church-clusters-and-wuhantravellers

6. Yang C (2020) Grace Assembly of God church to reopen next week after major disinfection. The Straits Times, 21 February 2020, https://www.straitstimes.com/ singapore/church-to-reopen-next-week-after-major-disinfection?

7. Yip WY (2020) CNY celebration by singing group led to second-largest cluster here. The Straits Times, 8 March 2020, https://www.straitstimes.com/singapore/cnycelebration-by-singing-group-led-to-second-largest-cluster-here?

8. Goh YH (2020) 1 in 5 patients went out or carried on with work despite being ill, The Straits Times, 11 March 2020, https://www.straitstimes.com/singapore/health/1-in-5patients-went-out-or-carried-on-with-work-despite-being-ill?

9. Teo J (2020) Singapore will have to change strategy if cases keep rising, says WHO expert. The Straits Times, 21 March 2020, https://www.straitstimes.com/singapore/ health/spore-will-have-to-change-strategy-if-cases-keep-rising?

10. Teo J (2020) Only two visitors per patient allowed at hospitals' general wards. The Straits Times, 31 January 2020, https://www.straitstimes.com/singapore/health/onlytwo-visitors-per-patient-allowed-at-hospitals-general-wards?

11. Mahmud AH (2020) SAF making thousands of calls a day to contact trace, check stayhome compliance as COVID-19 fight hits 'critical juncture', Channel NewsAsia, 4 April 2020, https://www.channelnewsasia.com/news/singapore/saf-contact-trace-stayhome-notice-shn-covid-19-12606752

12. Tang SK, Mahmud AH (2020) Singapore launches TraceTogether mobile app to boost COVID-19 contact tracing efforts, Channel NewsAsia, 20 March 2020, https://www. channelnewsasia.com/news/singapore/covid19-trace-together-mobile-app-contacttracing-coronavirus- 12560616

13. Passengers sue over coronavirus-hit Grand Princess cruise ship for over US\$1m, The Straits Times, 10 March 2020, https://www.straitstimes.com/world/united-states/ passengers-sue-over-coronavirus-hit-grand-princess-cruise-ship-for-over-us $1 \mathrm{~m}$ ?

14. Goh YH (2020) Not right to turn ship away. The Straits Times, 11 March 2020, https:// www.straitstimes.com/singapore/not-right-to-turn-ship-away-minister? 
15. Yuen S (2020) 233 new coronavirus cases; seven new clusters found. The Straits Times, 13 April 2020, https://www.straitstimes.com/singapore/233-new-cases-seven-newclusters-found?
16. Yong C (2020) 90\% of new cases in dorms as testing is stepped up. The Straits Times. 21 Apr 2020, https://www.straitstimes.com/singapore/90-of-new-cases-in-dorms-astesting-is-stepped-up?

Copyright: $\bigcirc 2020$ Yong Yau Ong. This is an open-access article distributed under the terms of the Creative Commons Attribution License, which permits unrestricted use, distribution, and reproduction in any medium, provided the original author and source are credited. 